"Approved for public release; distribution is unlimited."

Impacts of the Snake River

Drawdown Experiment on

Fisheries Resources in Little Goose

and Lower Granite Reservoirs, 1992

D. D. Dauble

D. R. Geist

September 1992

Prepared for the U.S. Army Corps

of Engineers - Walla Walla District

under a Related Services Agreement

with the U.S. Department of Energy

under Contract DE-AC06-76RLO 1830

Pacific Northwest Laboratory

Operated for the U.S. Department of Energy

by Battelle Memorial Institute

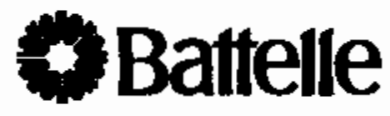




\title{
DISCLAIMER
}

This report was prepared as an account of work sponsored by an agency of the United States Government. Neither the United States Government nor any agency thereof, nor Battelle Memorial Institute, nor any of their employees, makes any warranty, expressed or implied, or assumes any legal liability or responsibility for the accuracy, completeness, or usefulness of any iniormation, apparatus, product, or process disclosed, or represents that its use would not infringe privately owned rights. Reierence herein to any specific commercial product, process, or service by trade name, trademark, manufacturer, or otherwise does not necessarily constitute or imply its endorsement, recommendation, or favoring by the United States Government or any agency thereof, or Battelle Mernorial Institute. The views and opinions of authors expressed herein do not necessarily state or reflect those of the United States Government or any agency thereof.

\author{
PACIFIC NORTHWEST LABORATORY \\ operated by \\ BATTELLE MEMORIAL INSTITUTE \\ for the \\ UNITED STATES DEPARTMENT OF ENERGY \\ under Contract DE-ACO6-76RLO 1830
}

Printed in the United States of America

Available to DOE and DOE contractors rirom the

Office of Scientific and Technical Information, P.O. Box t.2, Oak Ridge, TN 37831;

prices available from (615) 576-8401. FIS $626-8401$.

Available to the public from the National Technical Information Service, U.S. Department of Commerce, 5285 Port Royal Rd., Springfield, VA 22161. 
"Approved for public release; distribution is unlimited."

\section{IMPACTS OF THE SNAKE RIVER DRAWDOWN EXPERIMENT ON FISHERIES RESOURCES IN LITTLE GOOSE AND LOWER GRANITE RESERVOIRS, 1992}
D. D. Dauble
D. R. Geist

September 1992

Prepared for the U.S. Army Corps of Engineers - Walla Walla District under a Related Services Agreement with the U.S. Department of Energy Contract DE-AC06-76RLO 1830

Pacific Northwest Laboratory Richland, Washington 99352 


\section{EXECUTIVE_SUMMARY}

In March 1992, the U.S. Army Corps of Engineers initiated a test to help evaluate physical and environmental impacts resulting from the proposed future drawdown of Snake River reservoirs. Drawdown would reduce water levels in Snake River reservoirs and is being proposed as a solution to decrease the time it takes for salmon and steelhead smolts to migrate to the ocean. The Pacific Northwest Laboratory evaluated impacts to specific fisheries resources during the drawdown experiment by surveying Lower Granite Reservoir to determine if fall chinook salmon (Oncorhynchus tshawytscha) spawning areas and steelhead ( $O$. mykiss) access to tributary creeks were affected. In addition, shoreline areas of Little Goose Reservoir were monitored to evaluate the suitability of these areas for spawning by fall chinook salmon. Relative abundance of fish species in nearshore areas was also determined during the drawdown, and stranded resident fish and other aquatic organisms were observed.

Surveys and observations made during the drawdown indicated that known fall chinook salmon spawning areas upstream of Lower Granite Reservoir were not influenced by the 1992 drawdown experiment. No distinct habitat features were affected by the drawdown near Asotin, an area that would attract spawning of fall chinook salmon. Adult steelhead passage into Asotin Creek was not restricted by the drawdown. However, nearby Alpowa Creek was restricted by low flow, shallow delta and channels, and turbidity caused by resuspension of sediment within the delta area. In addition, a physical barrier was created by the lowered pool elevation. This, combined with the low flow, would prohibit passage of adult steelhead. Therefore, water levels in Lower Granite Reservoir similar to those experienced during the 1992 drawdown would prohibit escapement of adult steelhead to Alpowa Creek. These levels may warrant further consideration if this tributary is viewed as an indicator of potential impacts to steelhead spawning throughout an expanded drawdown area.

Based on substrate composition and low percentage of fines within the substrate, areas within 0.5 mile downstream of Lower Granite Dam appeared similar to those previously described for fall chinook spawning habitat in other locations within the Columbia River system. However, the slope of the banks was much steeper than fall chinook spawning habitat characterized in the Columbia River near Vernita Bar. A large gravel bar located immediately downstream of the turbine discharge area had substrate, gradient, and velocity characteristics that appeared suitable for fall chinook 
spawning. However, only a portion of the bar was exposed and no evidence of spawning was found. Additional information is needed to fully evaluate potential spawning habitat immediately below Lower Granite Dam. All other sites surveyed had characteristics considered unsuitable for spawning by fall chinook salmon, including two midchannel islands located 2.5 and 3.0 miles downstream of Lower Granite Dam.

Sixteen species of fish representing seven families were collected during the drawdown. General observations made in isolated pools indicated that small fish species were the most vulnerable to stranding and desiccation. Any nest-building species that spawns before a drawdown and remains near its nest may be more vulnerable to stranding and desiccation than broadcast spawners or fish that do not guard their nests. Freshwater clams (Anodonta spp.) and crayfish (Pacifasticus leniusculus) were the most noticeable aquatic organisms, other than fish, impacted by the drawdown. Exposure to increased temperatures and predators during the drawdown would result in substantial mortality to freshwater clams. Crayfish are likely to be impacted less because they are more mobile. 


\section{ACKNOWLEDGMENTS}

We thank Sara Wik (U.S. Army Corps of Engineers) for her oversight and guidance in development of study ohjectives. Dave Shreffler, Brett Tiller, Scott Abernethy, and Duane Neitzel of Pacific Northwest Laboratory assisted in field surveys. We also thank Dave Bennett (University of Idaho) for information on potential spawning locations and Roger Willms (Washington Department of Fisheries) for assistance in the field. 



\section{CONTENTS}

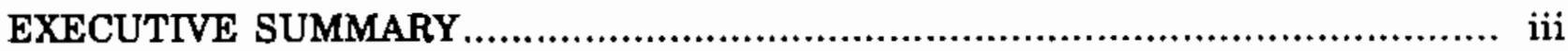

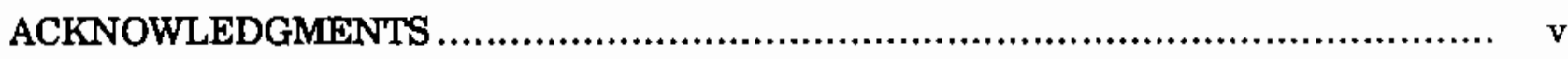

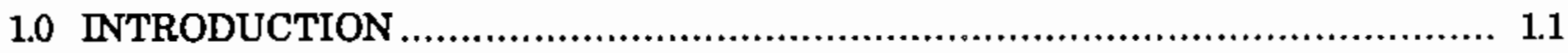

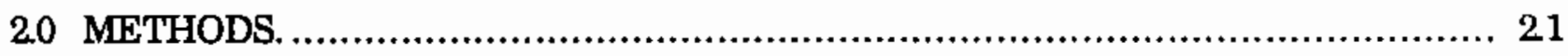

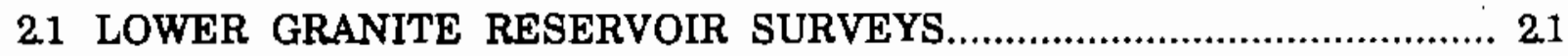

22 LITTLE GOOSE RESERVOIR SURVEYS ........................................ 21

2.2.1 Spawning Habitat Characterization .......................................... 21

2.2.2 Fisheries Assessment............................................................. 24

2.2.3 Other Aquatic Resources.......................................................... 2.4

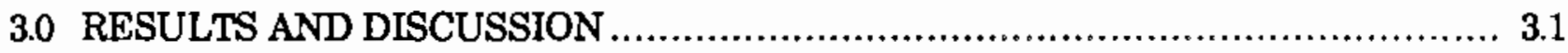

3.1 LOWER GRANITE RESERVOIR SURVEYS........................................ 3.1

3.2 LITTLE GOOSE RESERVOIR SURVEYS ........................................ 3.2

3.2.1 Spawning Habitat Characterization .......................................... 3.2

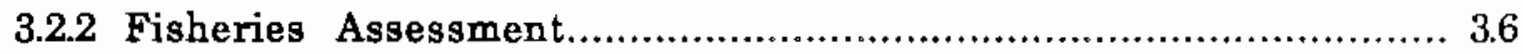

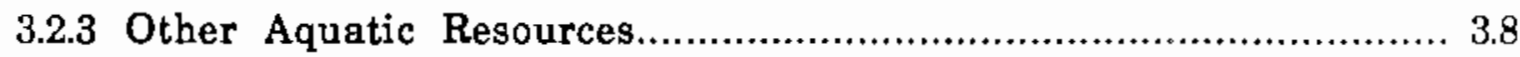

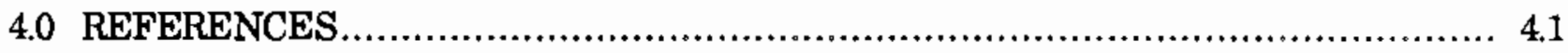




\section{EIGURES}

1.1 Location of the General Study Area within the Columbia River

Drainage

1.2 Schedule of the Reservoir Drawdown for Lower Granite and Little

2.1 Survey Sites in Lower Granite Reservoir

2.2 Location of Substrate Transects and Other Locations Where Substrate

Measurements were Taken Downstream of Lower Granite Dam

2.3 Location of Permanent Beach Seine and Electroshocking Stations

Downstream of Lower Granite Dam.

3.1 Substrate Composition for Shoreline Transects Downstream of Lower Granite Dam

3.2 Relative Abundance of Fish Taxa Collected in Nearshore Habitats Downstream of Lower Granite Dam.

\section{TABLE}

3.1 List of Fish Taxa Collected with Beach Seine and Electroshocker in Nearshore Habitats Below Lower Granite Dam 


\subsection{INTRODUCTION}

In March 1992, the U.S. Army Corps of Engineers (Corps) initiated a test to help evaluate potential physical and environmental impacts resulting from the drawdown of two reservoirs on the Snake River (Figure 1.1). The drawdown of lower Snake River reservoirs is being proposed as a solution to decrease the time it takes for salmon and steelhead smolts to migrate to the ocean. Initial plans were to reduce the pool elevation of Lower Granite and Little Goose reservoirs by up to 37 and 15 feet below the Minimum Operating Pool (MOP), respectively. Drawdown of Lower Granite reservoir occurred at the rate of 2 feet per day from March 1 through March 15. The reservoir was maintained at a level between 703 and 706 feet above mean sea level (MSL) from March 15 through March 26. It was then drafted to $697 \mathrm{MSL}$ and refilled at a rate of approximately 7 feet per day. One additional test took place on March 28, in which the reservoir was drafted from 712 to $709 \mathrm{MSL}$, and refill continued until a forebay elevation of 733 feet was achieved on April 1. Drawdown of Little Goose Reservoir occurred from March 15 through March 23 at the rate of 2 feet per day, during daylight hours only. The reservoir was then refilled at the rate of approximately 4 feet per day until a forebay elevation of 634 feet was achieved on March 28 (Figure 1.2).

Environmental concerns identified during the drawdown and lower pool elevations included impacts to anadromous and resident fisheries resources. Potential impacts include stranding of fish and other aquatic organisms, dewatering of spawning areas, and blocked passage to tributaries used for spawning. There was particular concern that fall chinook salmon Oncorhynchus tshawytscha spawning areas in Little Goose and Lower Granite reservoirs would be exposed during the drawdown. If salmon spawned in substrate exposed by the drawdown, eleutheroembryos and pre-emergent alevins remaining in the gravel could be dewatered and killed during the drawdown. Laboratory tests indicate that pre-emergent alevins of chinook salmon are killed if dewatered for 6 consecutive hours (Becker et al. 1983). Thus, monitoring was conducted to attempt to identify and characterize spawning areas before they were dewatered during the drawdown experiment.

The objective of our study was to evaluate impacts to specific fisheries resources during the drawdown experiment. We surveyed Lower Granite reservoir to determine if fall chinook salmon spawning areas in the free-flowing section of the Snake River 


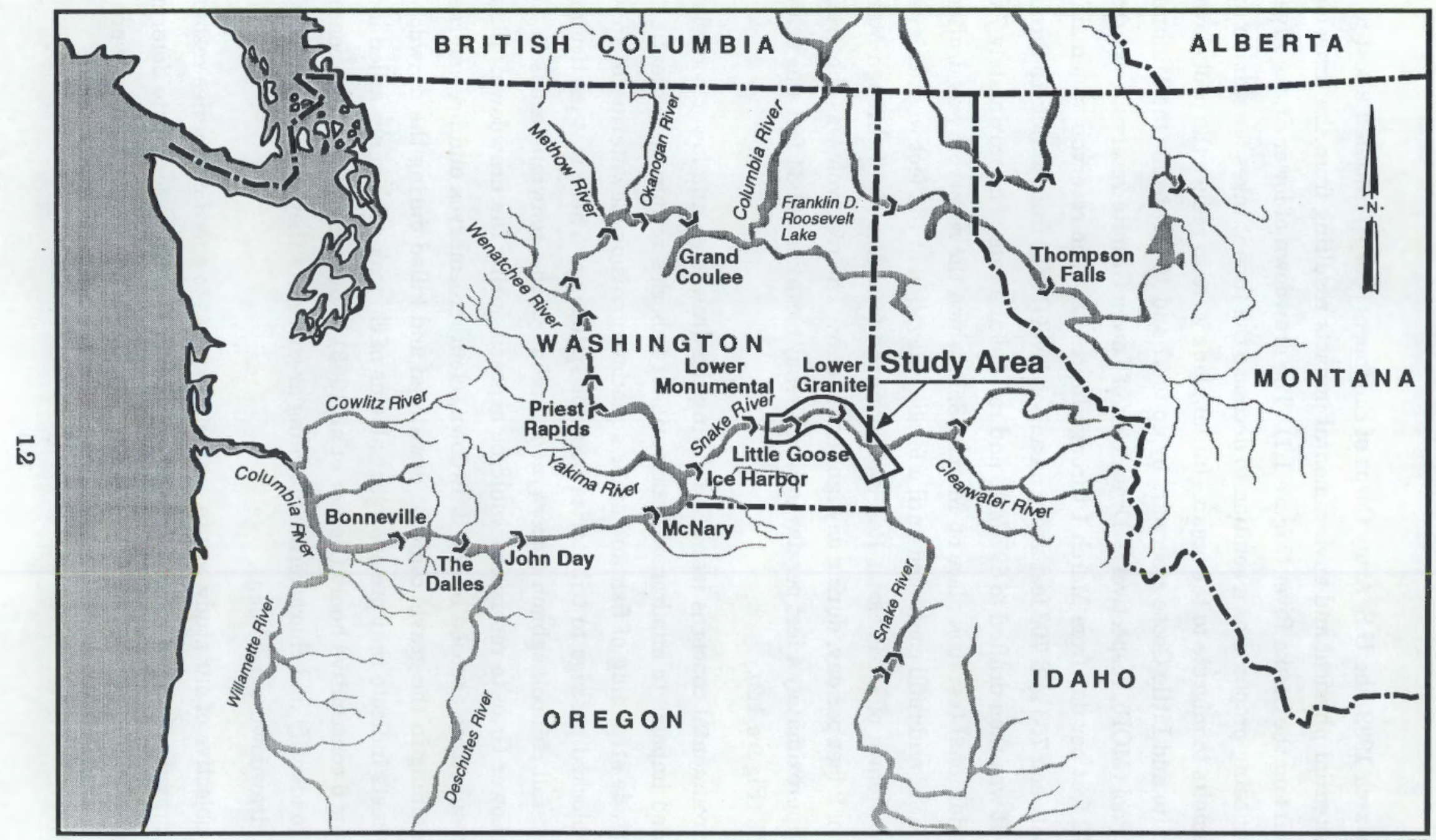

S9109069.1FR

EIGURE 1.1. Location of the General Study Area within the Columbia River Drainage 


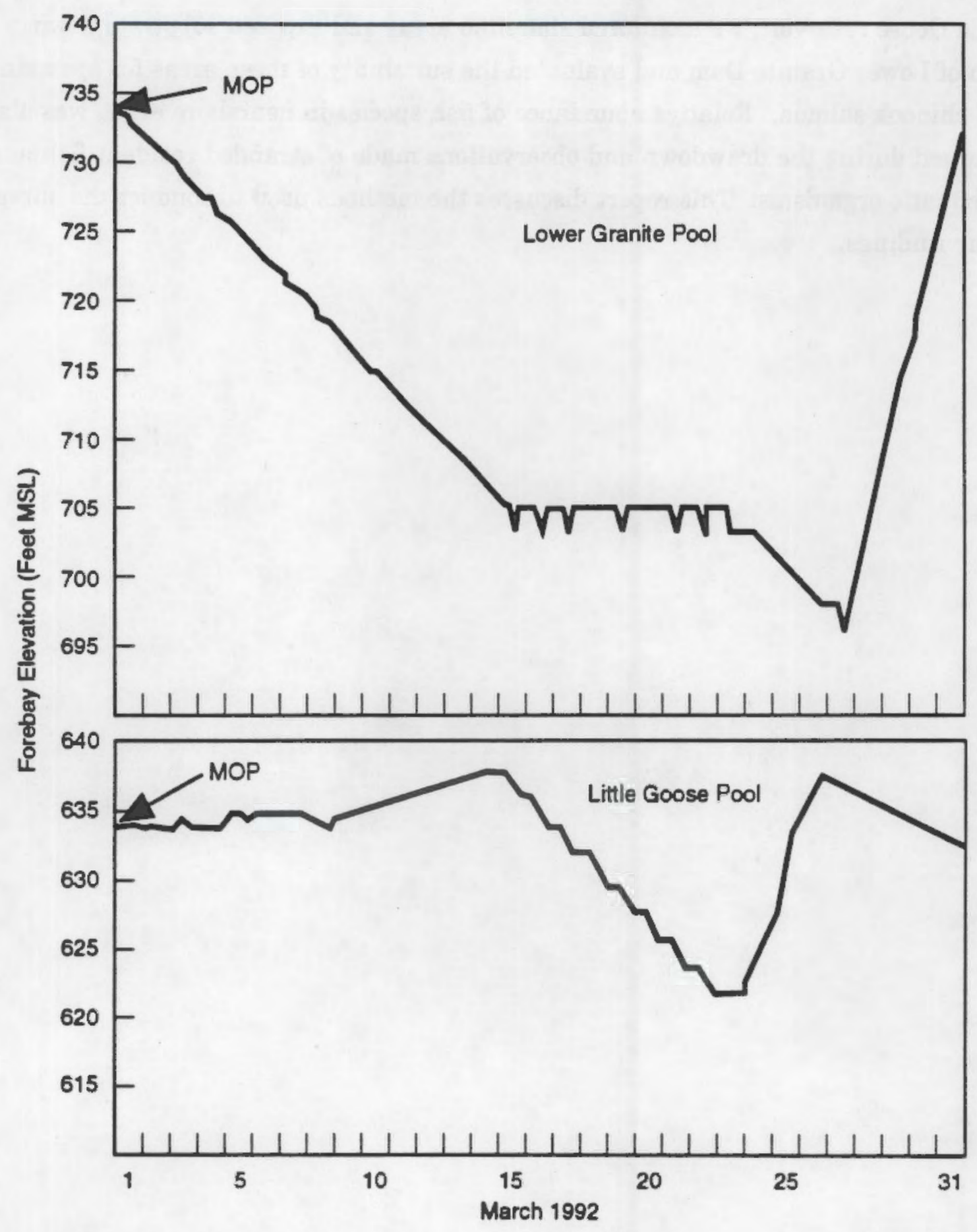

59205003.4

FIGURE 12. Schedule of the Reservoir Drawdown for Lower Granite and Little Goose Reservoirs 
upstream of Asotin were affected by the drawdown and to determine if access of steelhead (O. mykiss) to tributary creeks was affected at lowered pool levels. During the drawdown of Little Goose reservoir, we monitored shoreline areas and exposed substrate downstream of Lower Granite Dam and evaluated the suitability of these areas for spawning by fall chinook salmon. Relative abundance of fish species in nearshore areas was also determined during the drawdown and observations made of stranded resident fish and other aquatic organisms. This report discusses the methods used to conduct the surveys and our findings. 


\subsection{METHODS}

\subsection{LOWER GRANITE RESERVOIR SURVEYS}

Known and potential spawning sites for fall chinook salmon in the Snake River near Asotin, Washington (Figure 2.1), were surveyed during the drawdown period on March 3 and 13. Pool elevations were 4 feet and 24 feet below MOP on these dates, respectively. We walked shorelines where fall chinook salmon redds were previously observed (Bugert personal communication (a); Bugert et al. 1991) and other locations where spawning may have occurred. We also determined changes in shoreline elevation and searched for evidence of spawning activity (i.e., disrupted substrate and presence of eggs and/or newly emergent fry). The confluence of Asotin and Alpowa creeks was inspected for adult steelhead passage barriers on those dates. In addition, photographs regarding the drawdown influence zones were taken.

\subsection{LITTLE GOOSE RESERVOIR SURVEYS}

Studies were conducted in Little Goose reservoir to characterize potential spawning habitat for fall chinook salmon and to evaluate impacts to resident fish and other aquatic organisms.

\subsubsection{Spawning Habitat Characterization}

During the drawdown, we monitored shoreline areas and exposed substrate to identify potential spawning areas in Little Goose reservoir. Shoreline areas were monitored during daylight hours from March 17 to 24. Surveys were suspended once the reservoir began refilling. Study sites were selected based on recommendations of fisheries biologists familiar with the area and known features of fall chinook salmon spawning habitat (i.e., hydrologic, geomorphic, and hathymetric characteristics). We walked the shoreline in areas of likely spawning and searched for fall chinook salmon redds. At various locations, the shoreline area was excavated to search for eggs and/or emergent fry.

Sixteen substrate sampling stations were established to characterize substrate within the study area (Figure 2.2). Additional substrate measurements were taken in

(a) R. Bugert, Washington Department of Fisheries. Personal Communication to D.R. Geist, Pacific Northwest Laboratory, Richland, Washington. 


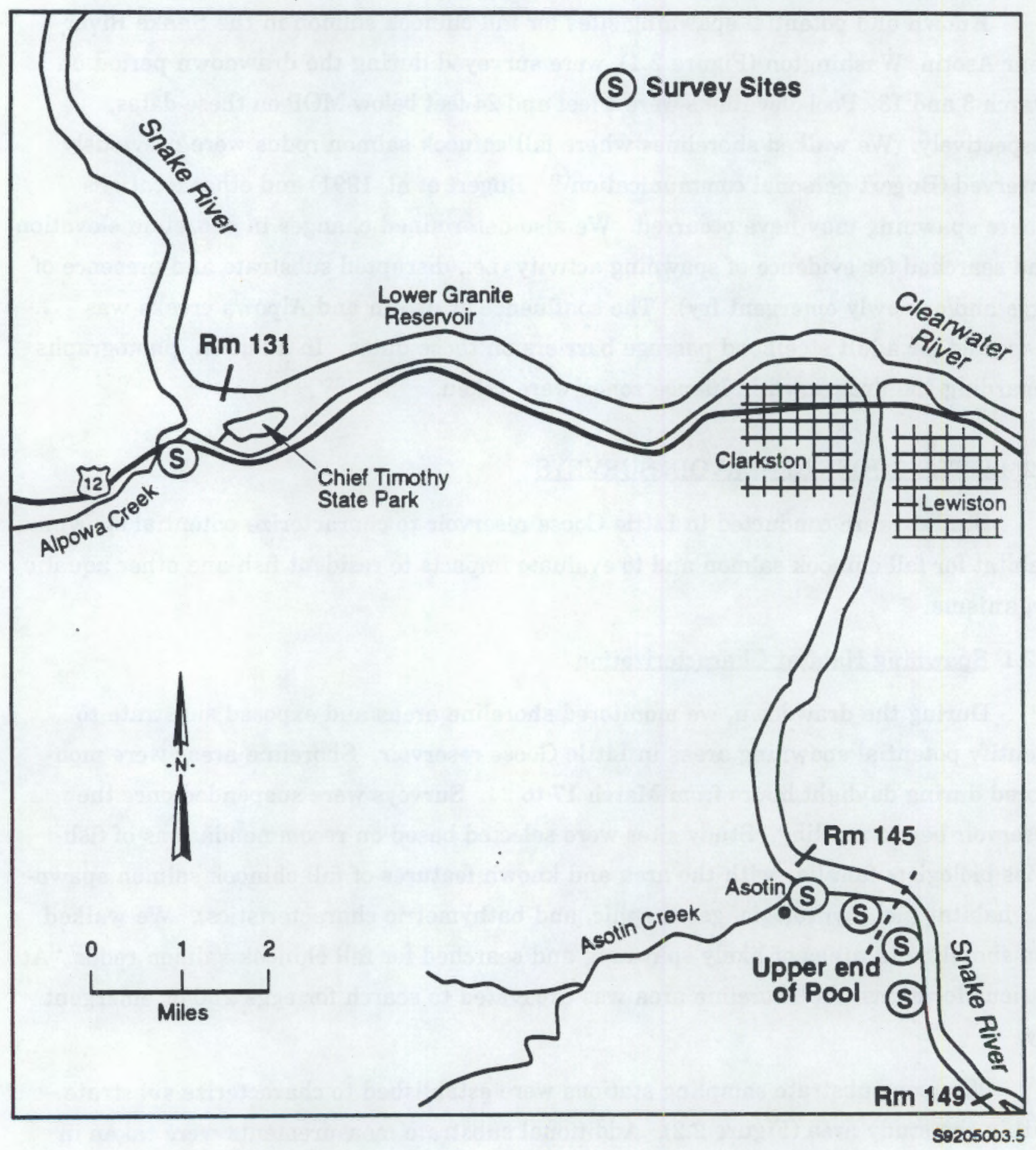

EIGURE 2.1. Survey Sites in Lower Granite Reservoir 


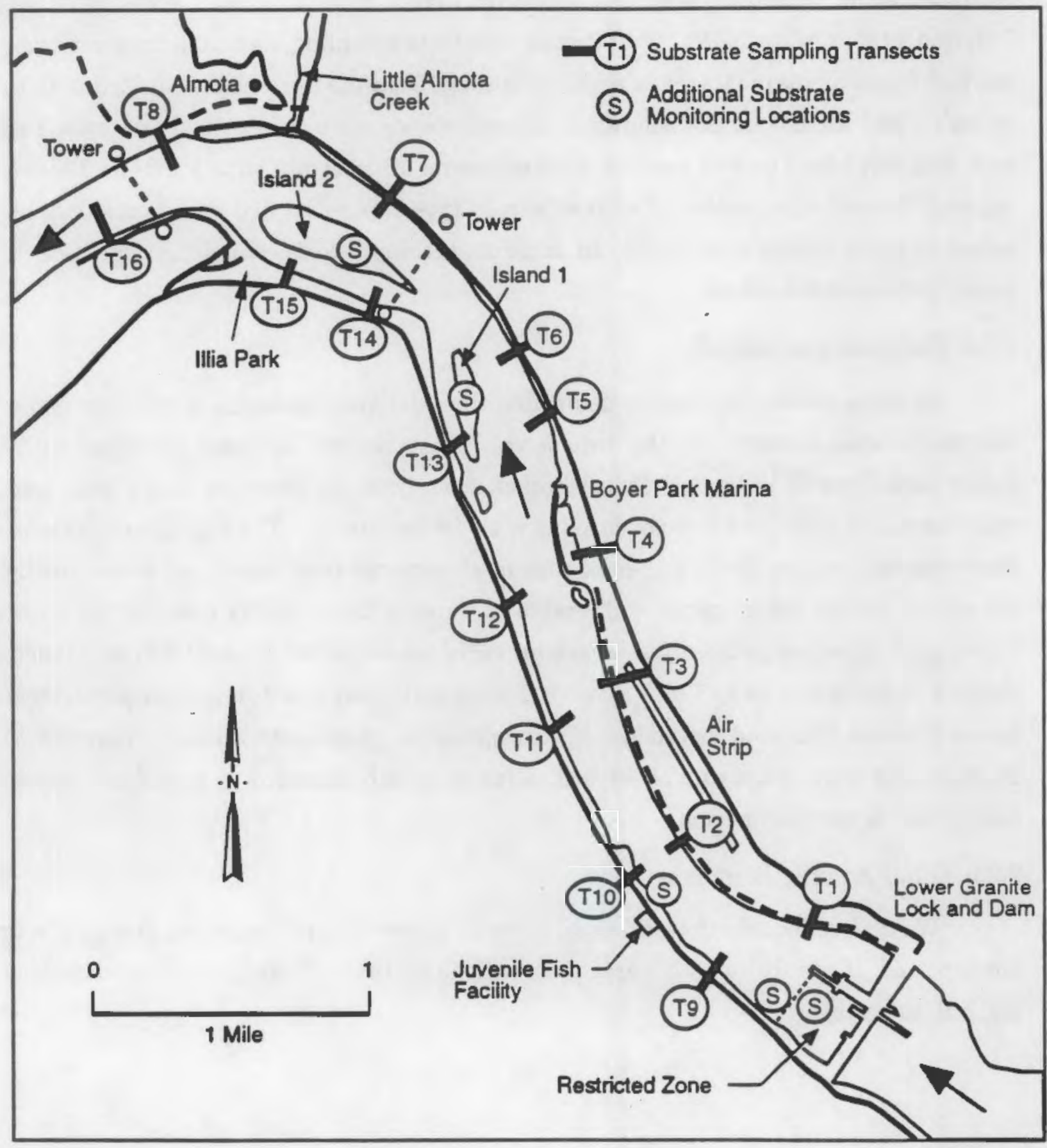

$59205003.6 \mathrm{~A}$

EIGURE 22. Location of Substrate Transects and Other Locations Where Substrate Measurements were Taken Downstream of Lower Granite Dam 
potential spawning areas, including two islands about 2.5 and 3.0 miles downstream of Lower Granite Dam, the south shoreline immediately downstream of the juvenile fish facility, and a gravel bar immediately downstream of the turbine discharge within the restricted zone. Substrate was measured from March 20 to 23 when the reservoir was 7,9 , and 11 feet below MOP. Within each substrate sampling station, a transect was marked approximately 60 feet in width extending from the normal pool elevation to the water's edge. Substrate and shoreline characteristics were qualitatively described within each transect based on five random measurements of substrate within a 8- by 20 -inch square. Percent composition of each substrate type was estimated based on surface visual analysis (Platts et al. 1983). In addition, the depth to fines and the degree of embeddedness were noted.

\subsubsection{Fisheries Assessment}

Surveys were conducted to determine the relative abundance of fish species in nearshore areas impacted by the drawdown. These surveys included sampling with a Smith Root Type IV backpack electroshocker, from both the shoreline and a boat, and with the use of a 30 - by 4 -foot beach seine with $1 / 8$ inch mesh. The purpose of the nearshore surveys was to identify species that might emerge from spawning areas during the drawdown and/or other species vulnerable to impacts from rapidly lowering water levels. These gear types are generally selective for early life-stages of resident fish and 0-age fall chinook (Dauble and Gray 1980). Surveys were restricted to a 4-mile area downstream of Lower Granite Dam and included collections at eight permanent stations (Figure 2.3). Photographs were taken and observations made on fish stranded in nearshore areas during the drawdown period.

\subsubsection{Other Aquatic Resources}

We also collected information on impacts to aquatic invertebrates during the drawdown period. Data included general observations on taxa affected, relative abundance, and habitat type. 


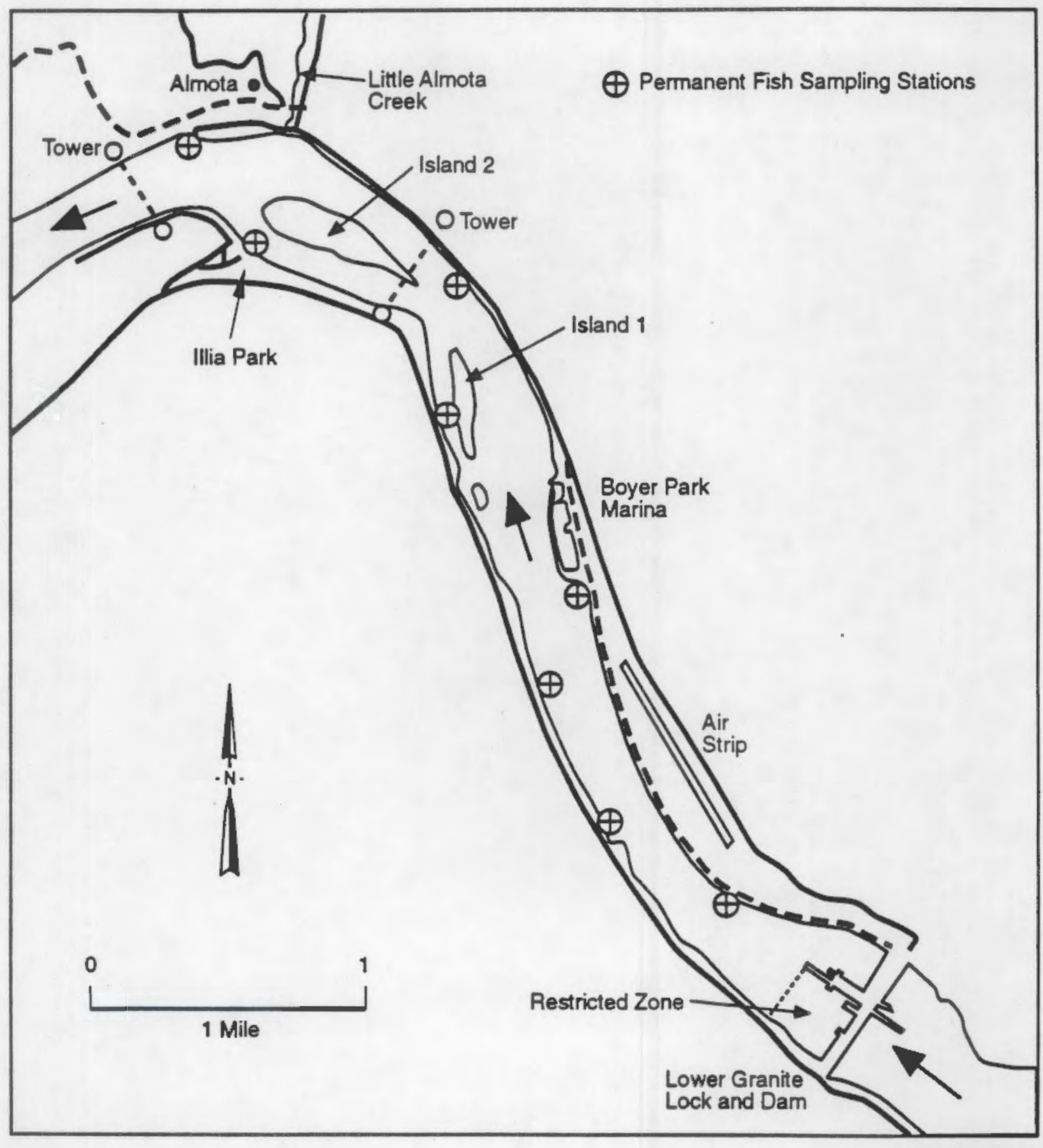

59205003.6

EIGURE 2.3. Location of Permanent Beach Seine and Electroshocking Stations Downstream of Lower Granite Dam 



\subsection{RESULTS ANDDISCUSSION}

\subsection{LOWER GRANITE RESERVOIR SURVEYS}

Washington Department of Fisheries found one redd at river mile (RM) 149.5 during the 1991 Snake River mainstem fall chinook salmon spawning surveys (Glen Mendel(a), personal communication). In 1990, two redds were confirmed on the Idaho side of the river at RM 148.4 and were the most downstream observed redds in recent years (Bob Bugert, personal communication (b); Bugert et al. 1991). During both drawdown surveys (March 3 and March 13), the Snake River at RM 149.3 was upstream of the drawdown influence zone. The upstream extent of the drawdown influence zone based on the March 13 survey (24 feet below MOP) was estimated to be near RM 146. Thus, it appeared that known fall chinook salmon spawning areas upstream of Lower Granite reservoir were not influenced by the 1992 drawdown experiment.

On March 13, the water surface at the upper end of the drawdown influence zone had dropped approximately 2 feet, exposing about 15 feet of shoreline. Within this 15 feet of exposed shoreline was a 10- to 12- foot band of cobble that extended up and down the left bank for about 0.5 mile. Closer to the river, sand comprised the predominant substrate. The cobble ranged in size from 2 to 10 inches and appeared to be an appropriate size for fall chinook spawning (Chambers 1956). However, there was a high percentage of sand and fines in the interstitial spaces and the substrate was highly embedded. Additionally, velocities within the reservoir confluence zone would be typically less than the 2.75 to 3.75 foot/second values reported for fall chinook in the mainstem Columbia River (Smith 1973). Thus, fall chinook use of these shoreline areas for spawning would likely be low. No distinct habitat features were affected by the drawdown in areas near Asotin that would attract spawning of fall chinook salmon.

Water levels at the mouth of Asotin Creek (RM 145.3) were influenced by the drawdown. Asotin Creek, at the confluence with Lower Granite Reservoir, had braided into four distinct channels by March 3. While three small channels presented difficult passage conditions for adult steelhead because of low flow, the main channel appeared passable (i.e., had sufficient flow, depth, and no barriers). This channel was deeply

(a) G. Mendel, Washington Department of Fisheries, personal communication to D.R. Geist, Pacific Northwest Laboratory, Richland, Washington.

(b) R. Bugert, Washington Department of Fisheries, personal communication to D.R. Geist, Pacific Northwest Laboratory, Richland, Washington. 
incised with the stream banks sloughing into the creek. During the March 13 survey, conditions had not changed appreciably and adult steelhead passage into Asotin Creek was not restricted by the drawdown.

Alpowa Creek (RM 130.6) was also surveyed on March 3 and March 13. Steelhead typically enter Alpowa Creek in early spring (March and April) and spawn approximately 3 miles upstream (Mark Shuck, personal communication(a)). On March 3, flows were sufficient to allow passage of adult steelhead into Alpowa Creek. However, during the March 13 survey, Alpowa Creek was not passable. On this date, a waterfall had been created by the lowered pool elevation within the creek delta. The water depth upstream and downstream of this barrier was less than 1 foot, prohibiting adult steelhead from jumping over the barrier. The resuspension of sediment within the delta area created turbidity levels that could result in migration blockage or avoidance for salmonids within the creek channel and delta (Cordone and Kelley 1961). Water levels in Lower Granite Reservoir similar to those experienced during the 1992 drawdown would probably prohibit escapement of adult steelhead to Alpowa Creek.

While the exact number of steelhead that spawn in Alpowa Creek is unknown, the recent observations suggest 10 to 12 adults could be affected during a spring drawdown (mark Schuck, personal communication ${ }^{(a)}$ ). The impact associated with loss of these steelhead is small when compared to the total resource. However, Alpowa Creek may be viewed as an indicator of potential cumulative impact to steelhead populations, which spawn in numerous small tributaries to the Snake River, should drawdown be expanded outside of Lower Granite Reservoir during this time period.

\subsection{LITTLE GOOSE RESERVOIR SURVEYS}

\subsubsection{Spawning Habitat Characterization}

The predominant substrate measured within the 16 substrate study sites was cobble- $40.3 \%$, gravel- $24.5 \%$, sand- $15.9 \%$, boulder- $13.5 \%$, and silt- $5.9 \%$. There was no apparent pattern in substrate distribution when only surface substrate composition was considered. On the right bank, cobble tended to be found in greater proportion to other

(a) M Schuck, Washington Department of Fisheries, personal communication to D. R. Geist, Pacific Northwest Laboratory, Richland, Washington.

(a) M Schuck, Washington Department of Fisheries, personal communication to D. R. Geist, Pacific Northwest Laboratory, Richland, Washington. 
substrate types at the upstream end of the reservoir, but this was not significant (Figure 3.1).

Within 0.5 mile downstream of Lower Granite Dam, silt or sand was not typically found in the upper 1 foot of the substrate. For example, at transect 1 , the substrate was predominantly loose cobble/gravel with fine material absent within 1 foot of the surface. On the left bank, substrate in the vicinity of the juvenile fish facility was predominantly clean angular rip-rap. The slope of both shorelines within 0.5 mile of the dam was usually greater than $45^{\circ}$ with the predominate substrate angular rip-rap and cobble. Rip-rap near normal water surface elevation was typically boulder size ( $>10$ inches diameter), and the size of the rip-rap decreased at lower elevations. Based on the low percentage of fines within the cobble substrate, these areas appeared similar to that previously described for fall chinook spawning in other locations of the Columbia River system (Burner 1951). However, the slope of the banks was much steeper than fall chinook spawning habitat characterized in the Columbia River at Vernita Bar by Chapman et al. (1983).

In general, substrate and shoreline configuration changed approximately 0.5 to 0.75 of a mile downstream of Lower Granite Dam. Rip-rap was replaced by natural river cobble and gravel, and the slope of the bank was more gradual, averaging about $30^{\circ}$. Shallow water gravel and sand bars became more prevalent. For example, approximately 0.5 mile downstream of Lower Granite Dam on the left bank a gravel bar was exposed on the seventh day of the drawdown ( 7 to 9 feet below MOP). At the time, this bar appeared to be a suitable fall chinook spawning area based on low gradient (approximately $7.5 \%$ ) and substrate characteristics. However, silt and clay material was within 3 inches of the surface and often immediately under the predominant substrate. Further, substrate was highly embedded with interstitial spaces filled with fine sand and sediment. Permeability of the substrate, and suitability for spawning, would be considered low because of the high percentage of sand and silt. Thus, all sites over 0.5 mile downstream of Lower Granite Dam had both substrate and velocity characteristics considered unsuitable for spawning by fall chinook salmon (reviewed in Reiser and Bjornn 1979).

In areas of shoreline development (e.g., Boyer Park Marina, Lower Granite Dam road, Almota grain elevators), the predominant substrate type was angular rip-rap. Sand and fine material increased in abundance as distance from the dam increased. 

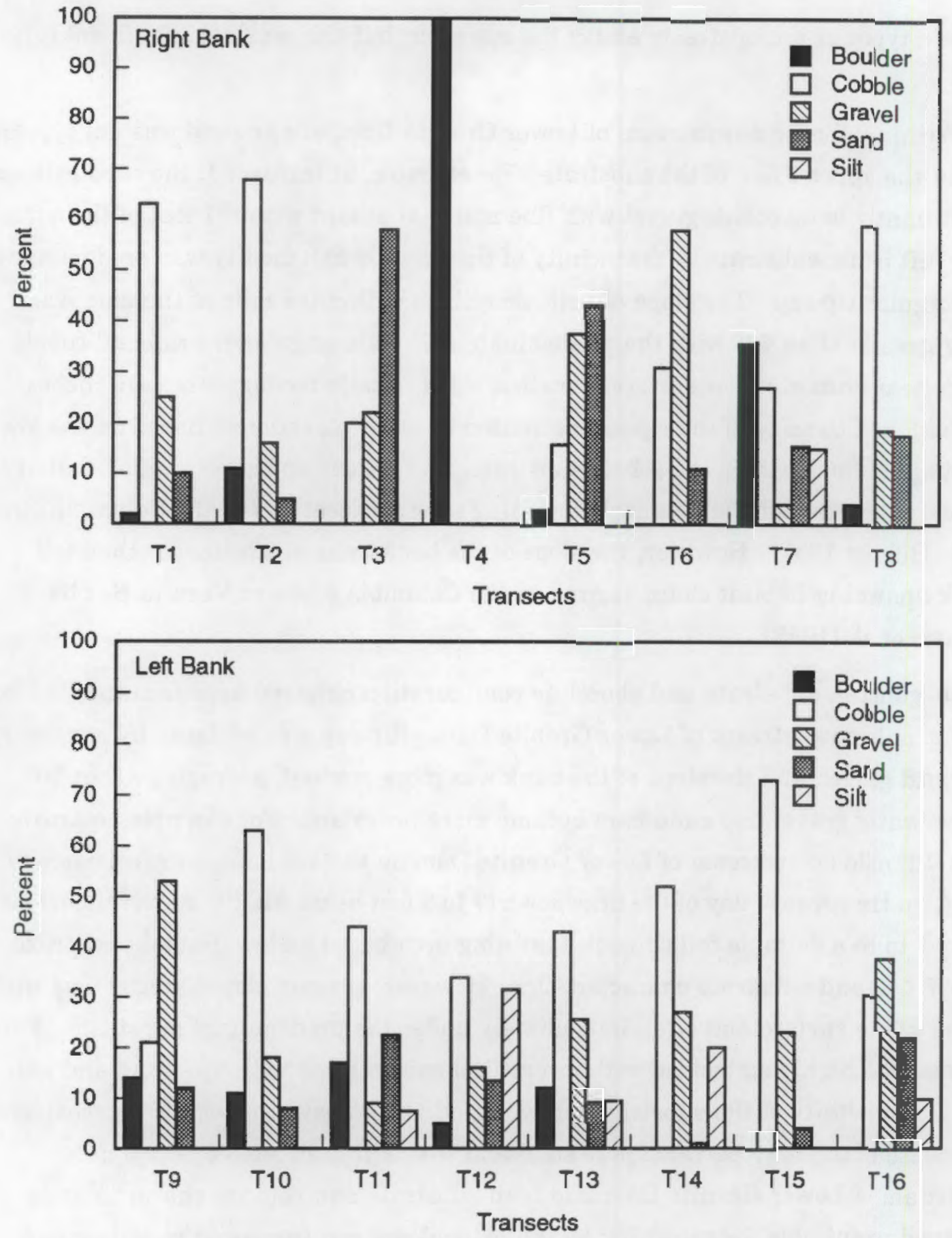

59205003.2

FIGURE 3.1. Substrate Composition for Shoreline Transects Downstream of Lower Granite Dam 
Rip-rap areas were often separated with long stretches of sandy beaches that were of low gradient. The confluence zone of intermittent and permanent streams was typically comprised of extensive mudflats. Vegetation was usually absent immediately along the shoreline, especially on the right bank, because of soil characteristics and water level fluctuations. Less rip-rap, and more sand and riparian vegetation was found on the left bank.

Substrate was also characterized in midchannel areas exposed during the drawdown to assess their potential use as fall chinook salmon spawning habitat. Two islands, 2.5 and 3 miles downstream of Lower Granite Dam (see Figure 2.3), were extensively surveyed because of mid-channel location and potential for fall chinook to spawn in areas with changes in cross-channel profiles (Dauble and Watson 1990). Potential spawning habitat on Island 1 ( 2.5 miles downstream of Lower Granite Dam) was surveyed from March 18 through 21 at $\sim 1, \sim 3, \sim 5$, and $\sim 7$ feet below MOP. The island was approximately 255 across at it widest point on day 6 of the drawdown. Two transects were measured on this island. The predominant substrate types were gravel (51\%) and cobble (49\%). Nearly 50 random excavations around the perimeter of the island revealed anaerobic mud (i.e., having dark coloration and hydrogen sulfide smell) within 3 to 6 inches of the surface. While sand was not predominant on the surface, hard packed sand was found immediately under the gravel/cobble substrate. The substrate distribution was uniform with no evidence of spawning. At normal pool elevations, velocities at the island are low (i.e., less than 2 feet/sec). This island contained a good size range of potential spawning substrate, and the shoreline slope and channel configuration were similar to locations used for spawning by fall chinook salmon in the Hanford Reach of the Columbia River (Dauble and Watson 1990). However, the exposed flat areas were covered with sediment, and the substrate had a high degree of embeddedness, substrate characteristics not suitable for successful spawning (reviewed in Reiser and Bjornn 1979). Although fall chinook may have spawned near Island 1 prior to the impoundment, it is unlikely that spawning would occur under existing conditions.

Potential spawning habitat on Island 2 (3 miles downstream of Lower Granite Dam) was surveyed on the fourth day ( 3 feet below MOP) and sixth day of the drawdown ( $\sim 6.5$ feet below MOP). The island was approximately 470 feet across at its widest point on day 6 of the drawdown. The predominant substrates were sand (37.4\%) and cobble (35.6\%), with nearly $90 \%$ of the cobble covered with fine sediment. Random excavations around the perimeter of the island below normal pool elevation revealed high concentra- 
tions of silt and sand immediately under the surface. The interstitial spaces of the cobble were packed with mud with the substrate highly embedded. Based on the high percentage of fine sediment, velocities in this location during normal pool operation are low. Fall chinook spawning at Island 2 would be unlikely because of the velocity and substrate characteristics.

On March 21, a gravel bar, approximately 3,000 square feet in size, was exposed immediately downstream of the turbine discharge area of Lower Granite Dam within the restricted zone. On March 22, more of the bar was exposed and it now extended about 0.25 mile downstream. The predominant substrates were cobble (average both days $62.5 \%$ ) and gravel (24.5\%). Random excavations around the perimeter of the bar revealed very little silt or fine sand within 6 to 8 inches of the surface. Coarse sand was found immediately under the substrate. On the southern edge of the gravel bar, the slope of the bank was approximately $45^{\circ}$. However, the slope was more gradual on all other sides of the bar, and velocities and substrate also appeared suitable for fall chinook spawning. We also looked for evidence of fall chinook spawning by excavating areas exposed by the drawdown, and looking for eggs, pre-emergent or emergent fry by dislodging substrate in 2 to 3 feet of water upstream of a long-handled dip net. No evidence of fall chinook spawning was found in the restricted zone during any of the excavations.

Additional information is needed to fully evaluate potential spawning habitat below Lower Granite Dam. This would include cross-sectional velocity profiles, bathymetry, and more comprehensive substrate characterization (i.e., percent fines and additional mapping).

\subsubsection{Fisheries Assessment}

We collected 16 species of fish representing seven families in nearshore habitats during the drawdown (Table 3.1). Cyprinids were the most diverse family present within the study site and were represented by five species. Almost all fish collected with the seine and electroshocker were juveniles and typically young-of-the-year. However, we also collected several adult largescale sucker (Catostomus macrocheilus) and sculpin (Cottus spp.), in addition to two adult steelhead in nearshore habitats with the backpack electroshocker.

Only three species of salmonids were collected from nearshore habitats during the drawdown period. No 0 -age chinook salmon were collected or observed. Juvenile largescale sucker comprised $92 \%$ of the fish collected by beach seine. Juvenile cyprinids, 
TABLE 3.1. List of Fish Taxa Collected with Beach Seine and Electroshocker in Nearshore Habitats Below Lower Granite Dam

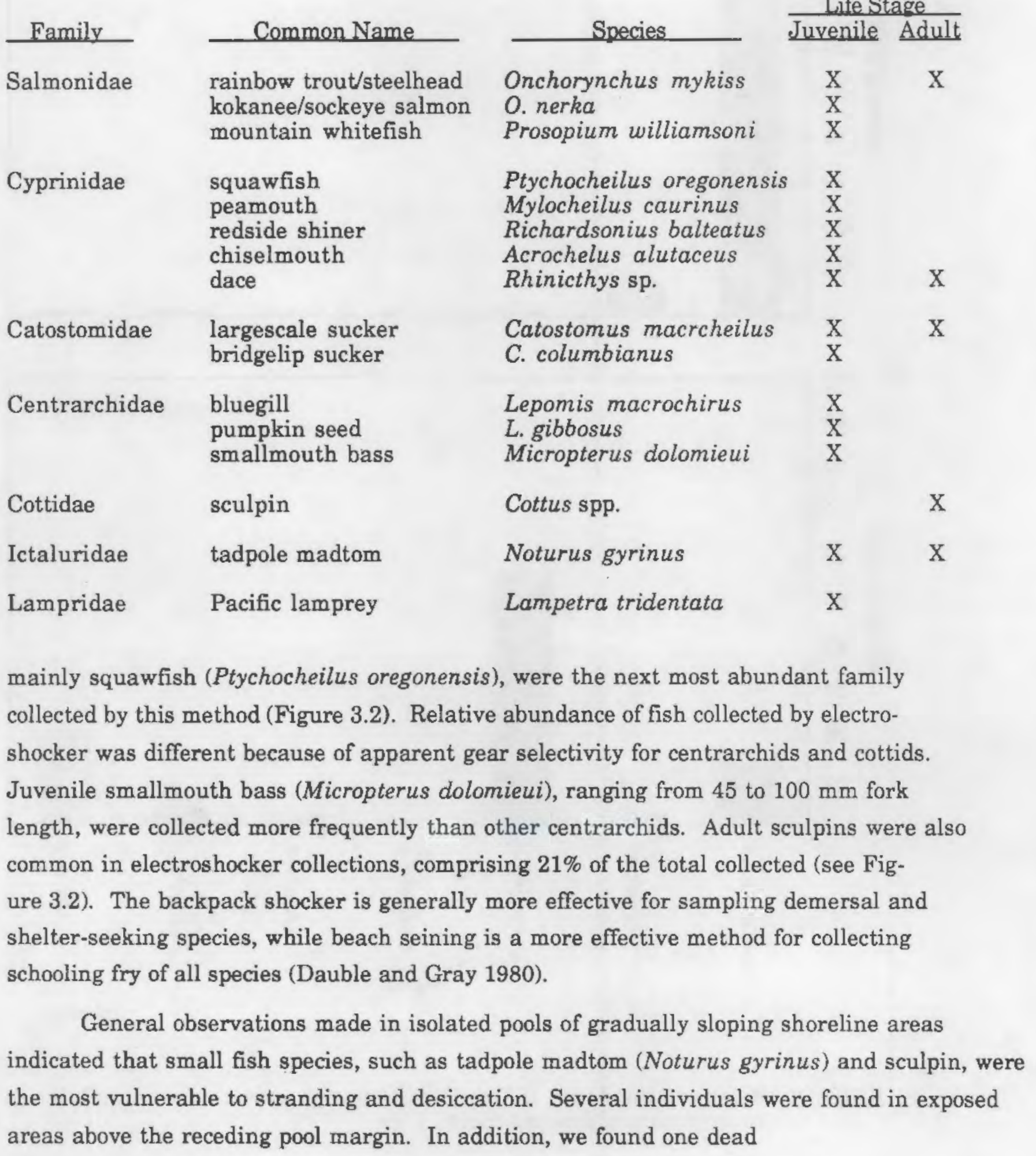


(a)

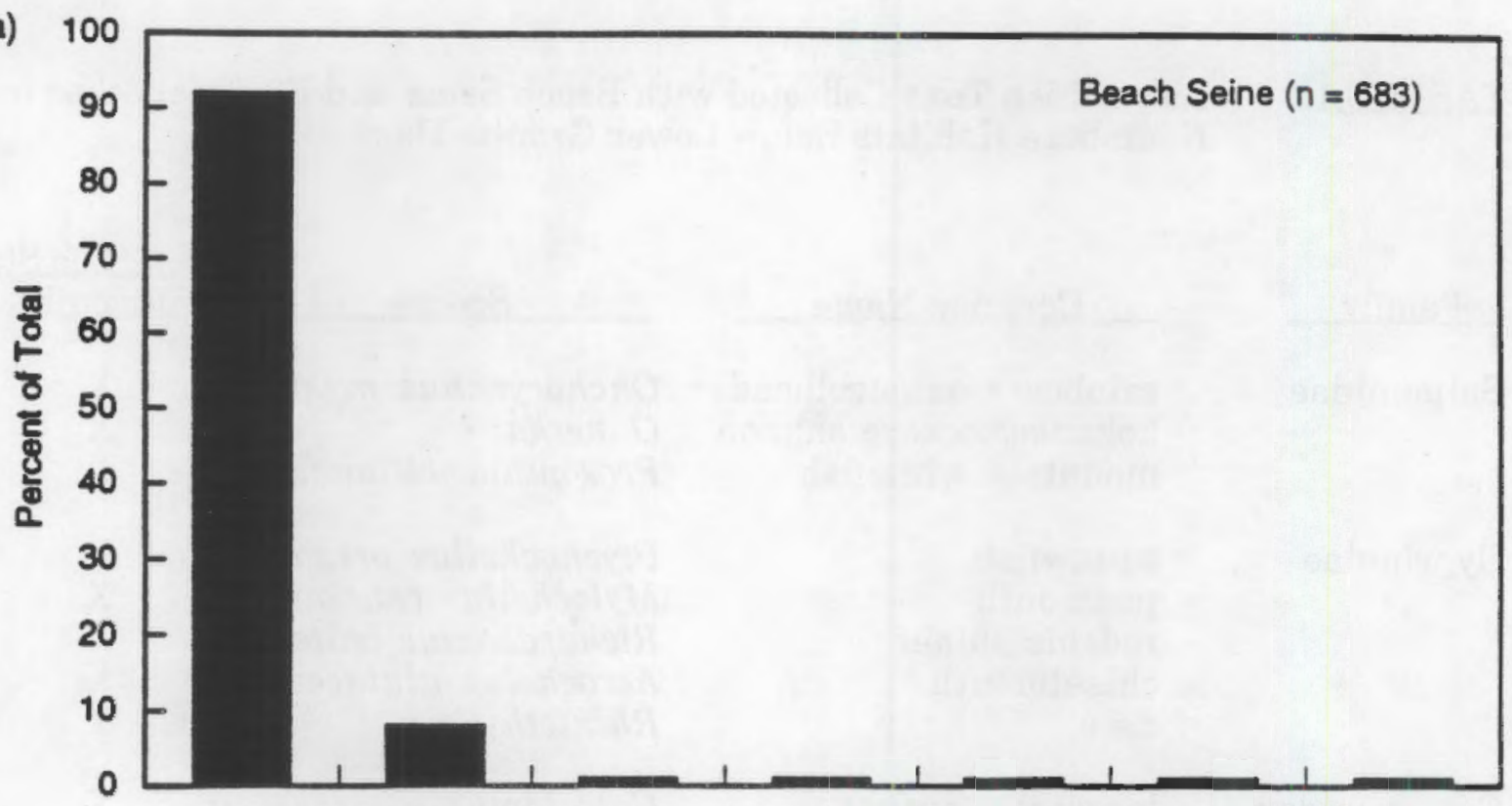

(b)
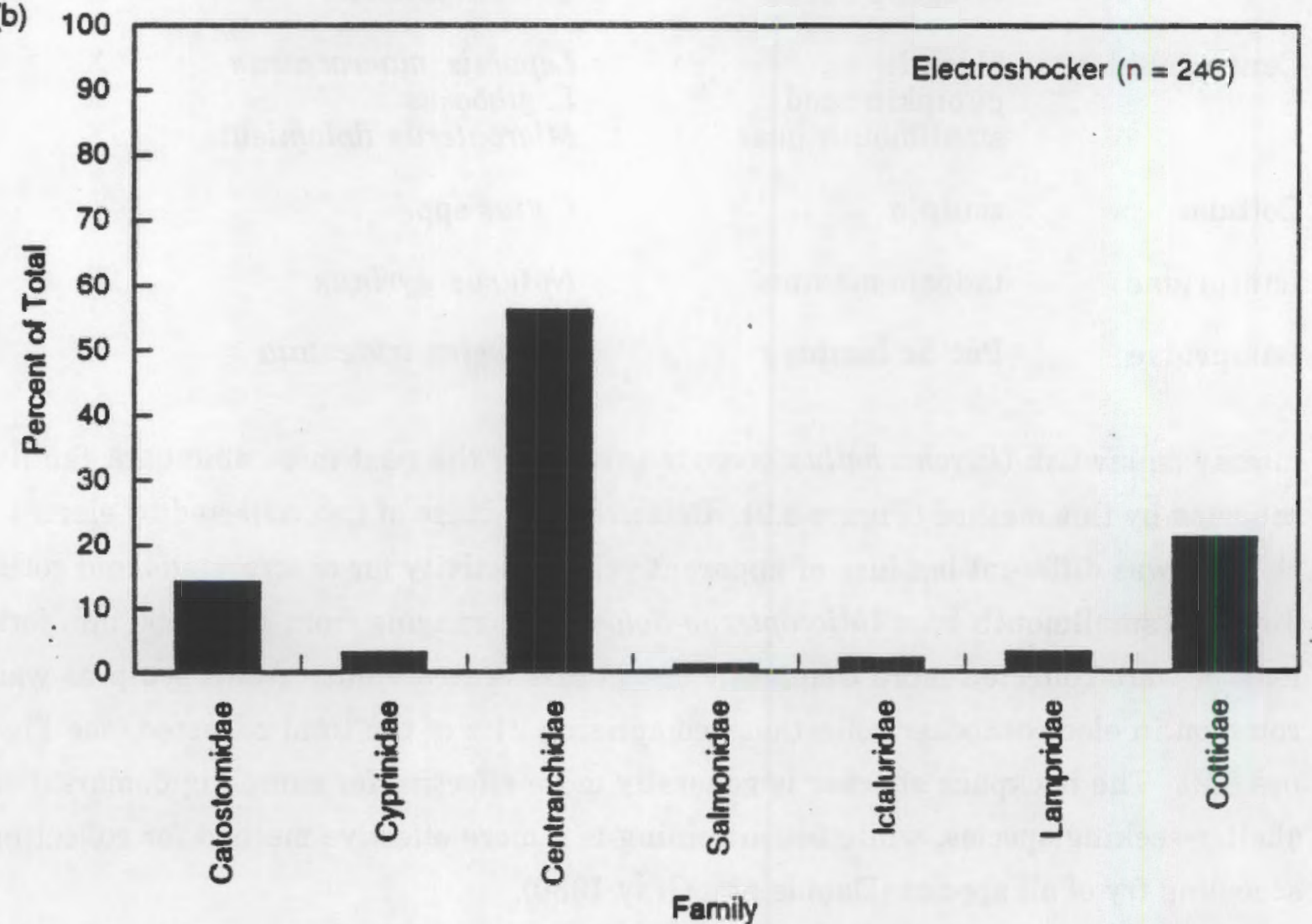

59205003.3

FIGURE 3.2. Relative Abundance of Fish Taxa Collected in Nearshore Habitats Downstream of Lower Granite Dam 
sculpin near an egg cluster. Thus, any nest-building species that spawns before a drawdown period and remains near its nest (i.e., sculpin, and bass) may be more vulnerable to stranding and desication than broadcast spawners or fish that do not guard their nests. Depending on the time of year, other species may remain in the substrate and become trapped during lowered water levels. Smallmouth bass fry, because of their high densities in the study area, would also be considered to be vulnerable to rapid lowering of water levels in the reservoir. Large pools, such as the Boyer Park boat basin, contained large schools of cyprinids and catostomids that were stranded during the drawdown period. We also found several juvenile lamprey (Lampetra tridentata), including ammocoetes, in some exposed mudflats. Juvenile lamprey were previously noted as vulnerable to lowered water levels in the Hanford Reach (Page 1976).

We observed a large congregation of gulls on the upper end of an island located 2.5 miles downstream of Lower Granite Dam (Island 1, see Figure 2.3). Sculpin were the most common fish species found in the dewatered margins of this island and were assumed to be vulnerable to predation by gulls. No other sign of avian predation on stranded fish and invertebrates was observed during the drawdown period.

We conducted electroshocker surveys at the confluence of Little Almota Creek and in the lower 300 feet of the creek on two occasions. Adult steelhead were found both in the Little Goose reservoir near the creek confluence and in the creek itself. We also collected eight juvenile rainbow/steelhead in the creek, ranging from about 14 to $20 \mathrm{~cm}$ FL. Thus, this tributary appears to be used by steelhead for both spawning and rearing. Little Almota Creek appeared passable to migrating fish even during the later stages of the drawdown. However, the 1992 drawdown of Little Goose reservoir was only to 12.5 feet below MOP, as compared to the proposed 40 foot below MOP.

\subsubsection{Other Aquatic Resources}

Freshwater clams (Asiatic clam Corbicula sp. and Anadonta spp.) and crayfish (Pacifasticus leniusculus) were the most noticeable aquatic organisms, other than fish, impacted by the drawdown. Corbicula were found in a variety of substrates, including mud and mixed cobble/gravel areas. We did not attempt to determine densities of stranded Corbicula. Anadonta were commonly exposed in shallow mudflats within the study area. For example, we found densities as high as 36 clams $/ 100$ feet of beach on March 18. We measured clam "tracks" from 1 to 10 feet long at this location which indicated some clams were moving downslope to the water in response to lowered water 
levels. However, many Anadonta were several feet above the water with little evidence of movement. Their ability to move toward the water is probably dependent on substrate texture, bank slope, and drawdown rate Some clams can survive desication for several days. However, exposure to increased temperatures and to predators during the drawdown would result in substantial mortality to these invertebrates.

Crayfish were common along the north shoreline, particularly in the boulder substrate adjacent to Boyer Park. We observed that crayfish tended to congregate near the wetted shoreline and that most of the female crayfish were "berried". Crayfish are mobile and able to hide in the crevices of rocks to avoid predation. Thus, they are less likely to be adversely impacted during short-term water level fluctuations than other lessmobile invertebrates like clams. However, an unknown number of crayfish may have been lost if they remained away from the water for extended periods of time during the drawdown.

In general, all aquatic organisms that reside in the littoral zone of reservoirs had the potential to be adversely impacted from desiccation during the drawdown. This included not only large invertebrates like clams and crayfish, but also smaller organisms such as attached insect larvae and amphipods. Changes in abundance of these fish food organisms, resulting from the drawdown, are the subject of additional ongoing studies. 


\subsection{REFERENCES}

Becker, C. D., D. A Neitzel, and C. S. Abernethy. 1983. "Effects of Dewatering on Chinook Salmon Redds: Tolerance of Four Development Phases to One-Time Dewatering." N.American. J Fish. Momt. 3:373-382.

Bugert, R. C., C. Busack, G. Mendel, K. Mendel, D. Marback, L. Ross, and J. Dedloff. 1991. Lower Snake_River Compensation Plan Lyons Ferry Fall Chinook Salmon Hatchery Program 1990 Evaluation Report. Prepared for the U.S. Fish and Wildlife Service, Boise, Idaho by the Washington Department of Fisheries, Olympia, Washington.

Burner, C. J. 1951. "Characteristics of Spawning Nests of Columbia River Salmon." U.S. Wild . Serv. Fish. Bull. 61:97-110.

Chambers, J. S. 1956 "Research Related to Study of Spawning Grounds in Natural Areas. U. S. Army Corps of Engineers. North Pacific Division, Eish. Eng Res. Prog. pp. 88-94.

Chapman, D. W., D. E. Weitkamp, T. L. Welsh, and T. H. Schadt. 1983. Effects Of Minimum Elow Regimes on Fall Chinook Salmon Spawning at Vernita Bar 1978-1982. Report to Grant County Public Utility District, Ephrata, Washington.

Cordone, A. J. and D. W. Kelley. 1961. "The Influence of Inorganic Sediment on the Aquatic Life of Streams". Calif Fish and Game. 47:431-454.

Dauble, D. D. and R. H. Gray. 1980. "Comparison of a Small Seine and a Backpack Electroshocker to Evalute Nearshore Fish Populations in Rivers." Prog Fish. Cult. 42:93-95.

Dauble, D. D., and D. G. Watson. 1990. Spawning and Abundance of Fall Chinook Salmon (Oncorhynchus tshawytscha) in the Hanford Reach of the Columbia River, 1948 1988. PNL-7289, Pacific Northwest Laboratory, Richland, Washington.

Page, T. L. 1976. Obseryations on Juvenile Salmon Stranding in the Columbia River April. 1976. Report to United Engineers and Constructors for Washington Public Power Supply System by Battelle, Pacific Northwest Laboratories, Richland, Washington.

Platts, W. S., W. F. Meghan, and G. W. Minshall. 1983. Methods for Evaluating Stream, Riparian and Biotic Conditions. Gen. Tech. Rep. INT-138, U.S. Department of Agriculture, U.S. Forest Service, Ogden, Utah.

Resier, D. W., and T. C. Bjornn. 1979. Habitat Requirements of Anadromous Salmonids. U.S. Department of Agriculture General Technical Report PNW-96, Idaho Cooperative Fishery Research Unit, University of Idaho, Moscow, Idaho.

Smith, A. K. 1973. "Development and Application of Spawning Velocity and Depth Criteria for Oregon Salmonids." Trans, Am. Fish_Soc. 10:312-316. 


\section{DISTRIBUTION}

No. of

Copies

\section{QEFSITE}

12 DOE/Office of Scientific and

Technical Information

$25 \quad$ S. Wik

U.S. Army Corps of Engineers

Walla Walla District

Building 602

City County Airport

Waila Walla, WA 99362-9295
No. of

Copies

Routing

R. M. Ecker

J. W. Falco

M. J. Graham

P. M. Irving

R. L. Skraggs

P. C. Hays (last)

\section{QNSITE}

\section{DOE Richland Field Office}

M. W. Tiernan

29 Pacific Northwest Laboratory

D. D. Dauble (10)

D.R. Geist (5)

D. A. Neizel (5)

H. E. Westerdahl

R. E. Lundgren

Publishing Coordination

Technical Report Files (5) 
